\title{
Thiobacillus plumbophilus spec. nov., a novel galena and hydrogen oxidizer
}

\author{
Elisabeth Drobner, Harald Huber, Reinhard Rachel, and Karl O. Stetter \\ Lehrstuhl für Mikrobiologie, Universität Regensburg, Universitätsstrasse 31, W-8400 Regensburg, Federal Republic of Germany
}

Received August 13, 1991/Accepted October 13, 1991

\begin{abstract}
From an uranium mine three strains of rodshaped, mesophilic, chemolithoautotrophic bacteria were isolated. They grow by oxidation of $\mathrm{H}_{2} \mathrm{~S}$, galena $(\mathrm{PbS})$ and $\mathrm{H}_{2}$. Anglesite $\left(\mathrm{PbSO}_{4}\right)$ is formed from galena. No ferrous iron is oxidized by the isolates. They grow between $\mathrm{pH} 4$ and 6.5 at temperatures of about 9 to $41{ }^{\circ} \mathrm{C}$ (optimum around $27{ }^{\circ} \mathrm{C}$ ). The $\mathrm{G}+\mathrm{C}$ content of the DNA is around $66 \mathrm{~mol} \%$. Based on their ability to oxidize sulfur compounds, the new organisms belong to the genus Thiobacillus. No significant homology with Thiobacillus ferrooxidans and Thiobacillus cuprinus was detected by DNA-DNA hybridization. Therefore the new isolates represent a new species within the genus Thiobacillus. Based on the unusual growth on galena, we name the new species Thiobacillus plumbophilus (type strain Gro7; DSM 6690).
\end{abstract}

Key words: Thiobacillus - Galena - Hydrogen oxidation - Chemolithotrophic

Members of the bacterial genus Thiobacillus are characterized by their ability to oxidize reduced sulfur compounds (Vishniac 1974). Different species exhibit further physiological properties like oxidation of ferrous iron (Colmer and Hinkle 1947), aerobic hydrogen oxidation (Drobner et al. 1990), nitrate reduction (Baalsrud and Baalsrud 1954) and growth on organic substrates (Guay and Silver 1985; Huber and Stetter 1990). T. ferrooxidans (Colmer and Hinkle 1947), T. prosperus (Huber and Stetter 1989) and T. cuprinus (Huber and Stetter 1990) are able to oxidize the sulfur moiety of sulfidic ores and, as a result of this property, are important organisms in bioleaching (Kelly 1988).

The leaching-efficiency of $T$. ferrooxidans parallels the solubility of the metal sulfide offered (Torma and Sakaguchi 1978). Therefore weakly soluble sulfides like cinnabar $(\mathrm{HgS})$ and galena $(\mathrm{PbS})$ are only slowly attacked by

Offprint requests to: $\mathrm{K}$. O. Stetter this organism. According to Kingma and Silver (1980) the oxidation of galena by $T$. ferrooxidans is enhanced in the presence of ferrous iron and elemental sulfur.

Here we describe the isolation and properties of a novel group of organisms which oxidize $\mathrm{PbS}, \mathrm{H}_{2} \mathrm{~S}$ and $\mathrm{H}_{2}$.

\section{Materials and methods}

\section{Strains}

The type strain of Thiohacillus ferrooxidans (ATCC 23270) was obtained from the American Type Culture Collection (ATCC), Rockville, MD.. T. cuprinus (DSM 5495) was isolated in our own laboratory (Huber and Stetter 1990).

\section{Culture conditions}

T. ferrooxidans was grown in "9K"-medium (Silverman and Lundgren 1959), T. cuprinus in the mineral salts medium "MI" (Huber et al. 1986), adjusted to $\mathrm{pH} 3.5$ with sulfuric acid. If not mentioned otherwise the new isolates were cultivated in " $9 \mathrm{~K}$ "-medium adjusted to $\mathrm{pH} 4.0$ and supplemented with synthetic lead sulfide (PbS; $0.3 \mathrm{~g} / 30 \mathrm{ml}$ ). All organisms were grown under shaking $(100 \mathrm{rpm})$ in 100-ml Erlenmeyer flasks containing $30 \mathrm{ml}$ medium.

Growth on $\mathrm{H}_{2} \mathrm{~S}$ was determined in a $\mathrm{H}_{2} \mathrm{~S}$ /oxygen gradient formed within soft agar. Five millilitres sterile " $9 \mathrm{~K}$ " agar-medium. $\mathrm{pH} \mathrm{2}$, containing $0.025 \% \mathrm{Na}_{2} \mathrm{~S}$ and $2 \%$ agar were filled into 28-ml rolltubes (Schott Mainz, FRG). After solidification, a soft agar overlay consisting of $10 \mathrm{ml}$ " $9 \mathrm{~K}$ " medium, $\mathrm{pH} 4$, containing $0.2 \%$ agar was prepared. After cooling down to $53 \mathrm{C}, 0.5 \mathrm{ml}$ of a culture of isolate Gro3, Gro7 or Gro8 were mixed into the liquid soft agar (final concentration : $5 \times 10^{5}$ cells $/ \mathrm{ml}$ ) and an overlay above the $\mathrm{H}_{2} \mathrm{~S}$ containing layer was poured. The tubes were sealed under air by stoppers and were incubated at $28 \mathrm{C}$.

Ferrous sulfate $(4 \%, w / v)$, sodium thiosulfate $(0.5 \%)$, potassium tetrathionate $(0.5 \%)$, elemental sulfur $(0.05 \%)$, synthetic metal sulfides $\left(\mathrm{Ag}_{2} \mathrm{~S}, \mathrm{CdS}, \mathrm{CuS}, \mathrm{CuS}_{2}, \mathrm{FeS}, \mathrm{HgS}, \mathrm{MoS}_{2}, \mathrm{Sb}_{2} \mathrm{~S}_{3}, \mathrm{SnS}, \mathrm{ZnS}\right.$; each $1.7 \%$ ), natural ores (galena, pyrite, chalcopyrite, sphalerite. pitch blend, each 1.7\%; Huber and Stetter 1990), complex organic substrates (yeast extract, meat extract, peptone, casamino acids; each $0.05 \%$ ), sugars (e.g. arabinose, glucose, galactose, lactose; each $0.1 \%$ ), amino acids (DL-alanine, L-glutamic acid, DL-valine; each $0.1 \%$ ) and organic acids (formiate, acetate, lactate, malate, propionate, pyruvate; each $0.1 \%$ ) were tested as possible substrates. Aerobic oxidation of molecular hydrogen was assayed in mineral 
salts medium „M1“ adjusted to $\mathrm{pH}$ 6.0. The culture conditions were described elsewhere (Drobner et al. 1990).

Batch cultures were grown in a 851 enamel-protected fermentor (HTE, Bioengineering, Wald, Switzerland) either on $\mathrm{PbS}(30 \mathrm{~g} / 55$ 1; gassing by 21 of air per min) or on a mixture of $\mathrm{H}_{2} / \mathrm{CO}_{2} /$ air $(80: 20: 3,200 \mathrm{kPa})$.

\section{Determination of growth}

Growth was detemined by direct cell counting in a Thoma chamber (depth $0.02 \mathrm{~mm}$ ).

\section{Fluorescence microscopy}

For the visualization of cells attached to solid particles a modified DAPI staining method was used (Huber et al. 1985).

\section{Electron microscopy}

For electron microscopy, cells were fixed with glutaraldehyde $(2.5 \%)$ and formaldehyde $(2 \%)$, applied to a carbon coated grid, washed with double distilled water and air dried. The grids were shadowed with platinum in an Edwards 306 shadowing unit.

For ultrathin sections, cells of an exponentially growing culture were fixed for $30 \mathrm{~min}$ by adding glutaraldehyde $(0.5 \%)$ and formaldehyde $(3 \%)$ to the culture medium. The harvested cells were resuspended in phosphate buffer $(\mathrm{pH}$ 6.1) supplemented with glutaraldehyde $(0.5 \%)$ and formaldehyde $(3 \%)$ and fixed again for $30 \mathrm{~min}$. Cells were washed twice with Tris-buffer ( $\mathrm{pH}$ 7.4), dehydrated successively with $50 \%$ ethanol, $70 \%$ ethanol, and a mixture of $95 \%$ ethanol plus LR Withe $(1+2)$ at $-20{ }^{\circ} \mathrm{C}$ and finally transferred into pure LR Withe $\left(2 \times 1 \mathrm{~h}\right.$ at $-20^{\circ} \mathrm{C}, 1 \times 12 \mathrm{~h}$ at $4{ }^{\circ} \mathrm{C}$ ). The blocks were polymerized at $50{ }^{\circ} \mathrm{C}$ for 4 days. The ultrathin sections were stained with uranylacetate $(2 \%)$ for $10 \mathrm{~min}$ and lead-citrate for $2 \mathrm{~min}$. Electron micrographs were taken with a Philips CM12 electron microscope at an operating voltage of $100 \mathrm{kV}$.

\section{Tolerance against heavy metals}

Resistance to antimony, arsenic, cadmium, cobalt, copper, molybdenum, nickel, silver, uranium and zinc was determined in the presence of $\mathrm{PbS}$. Stock solutions and tested concentrations were the same as described (Huber and Stetter 1989, 1990). Tolerance against iron was tested with and without $\mathrm{PbS}$. $\mathrm{FeSO}_{4}$-solution was added with the final $\mathrm{Fe}^{2+}$-concentrations (mmol/l) $0.02,0.2,2,4$.

\section{Quantitative determination of sulfate}

Sulfate was determined gravimetrically after precipitation by $\mathrm{BaCl}_{2}$ (Williams 1979).

\section{Determination of hydrogenase activity}

- Cultures grown to stationary phase were resuspended in hydrogenase buffer. To destroy the cell wall, lysozyme solution was added $\left(1000 \mathrm{U} ; 35^{\circ} \mathrm{C} ; 30 \mathrm{~min}\right)$. Hydrogenase activity was determined photometrically measuring the reduction of methylene blue (Schink and Schlegel 1979; Segerer et al., in preparation).

\section{Hydrogen analysis}

$\mathrm{H}_{2}$ was analysed on a Hewlett Packard 5890 gas chromatograph (stainless steel column, packed with Molecular Sieve 5A, Supelco; oven temp. $140{ }^{\circ} \mathrm{C}$, inject. temp. $190{ }^{\circ} \mathrm{C}$, detector temp. $200^{\circ} \mathrm{C}$, detector TCD).

\section{NMR analysis}

To identify the product of aerobic hydrogen oxidation $\mathrm{H}_{2}$ was substituted by $\mathrm{D}_{2}$ and HDO was determined by NMR spectroscopy using a Bruker MSL300 NMR spectrograph.

\section{Isolation of DNA}

DNA was prepared as described earlier (Wildgruber et al. 1982).

\section{DNA base composition}

The $\mathrm{G}+\mathrm{C}$ content of the DNAs was determined by melting point analysis in $0.1 \times$ SSC (Marmur and Doty 1962) and by HPLC chromatography of the nucleotides after digestion of the DNAs with nuclease P1 (Zillig et al. 1980). Calf thymus DNA $(\mathrm{G}+\mathrm{C}$ content $42 \mathrm{~mol} \%$ ) was used as reference.

\section{DNA-DNA homology}

DNA-DNA hybridizations were performed (König 1984) after radioactive in-vitro labelling of the DNA by nick translation (Kelly et al. 1970) using the filter technique (Gillespie and Gillespie 1971; Birnstiel et al. 1972).

\section{Results}

\section{Enrichment and isolation}

Aerobic samples of waters, sediments and ore particles with an original temperature of $11{ }^{\circ} \mathrm{C}$ and a $\mathrm{pH}$-value of 6.5 were taken in an uranium mine near Großschloppen, FRG. In the laboratory sterile mineral medium supplemented with $0.5 \mathrm{~g}$ of the sulfidic ore galena $(\mathrm{PbS})$ was inoculated with about $1 \mathrm{~g}$ of the material of different samples. After two weeks of incubation at $28^{\circ} \mathrm{C}$, rod-shaped organisms were visible in the enrichment attempts of the samples Gro3, Gro7 and Gro8. The enrichment cultures were purified by serial dilution carried out at least three times in the ore-containing medium. The isolates were designated the same as the samples.

\section{Morphology}

Tiny rods, either motile in suspension or attached to the metal sulfide (about $80 \%$ ) were visible by phase contrast microscopy. The cells were up to $3 \mu \mathrm{m}$ long and $0.15-0.25 \mu \mathrm{m}$ in width. They possessed one polar flagellum (Fig 1). The cells showed a negative Gramstaining reaction. Ultrathin sections of cells grown on $\mathrm{H}_{2}$ revealed a slime layer covering the cell wall (Fig. 2, arrow), possibly responsible for cell aggregation.

\section{Storage}

Cultures grown on $\mathrm{PbS}$ and stored at room temperature without shaking served as inocula for at least 1 year. Cells cultivated on $\mathrm{PbS}$ or $\mathrm{H}_{2}$ kept their variability for at least 18 months when they had been stored at $-20^{\circ} \mathrm{C}$ or at $-140{ }^{\circ} \mathrm{C}$ (liquid nitrogen; gas phase). 

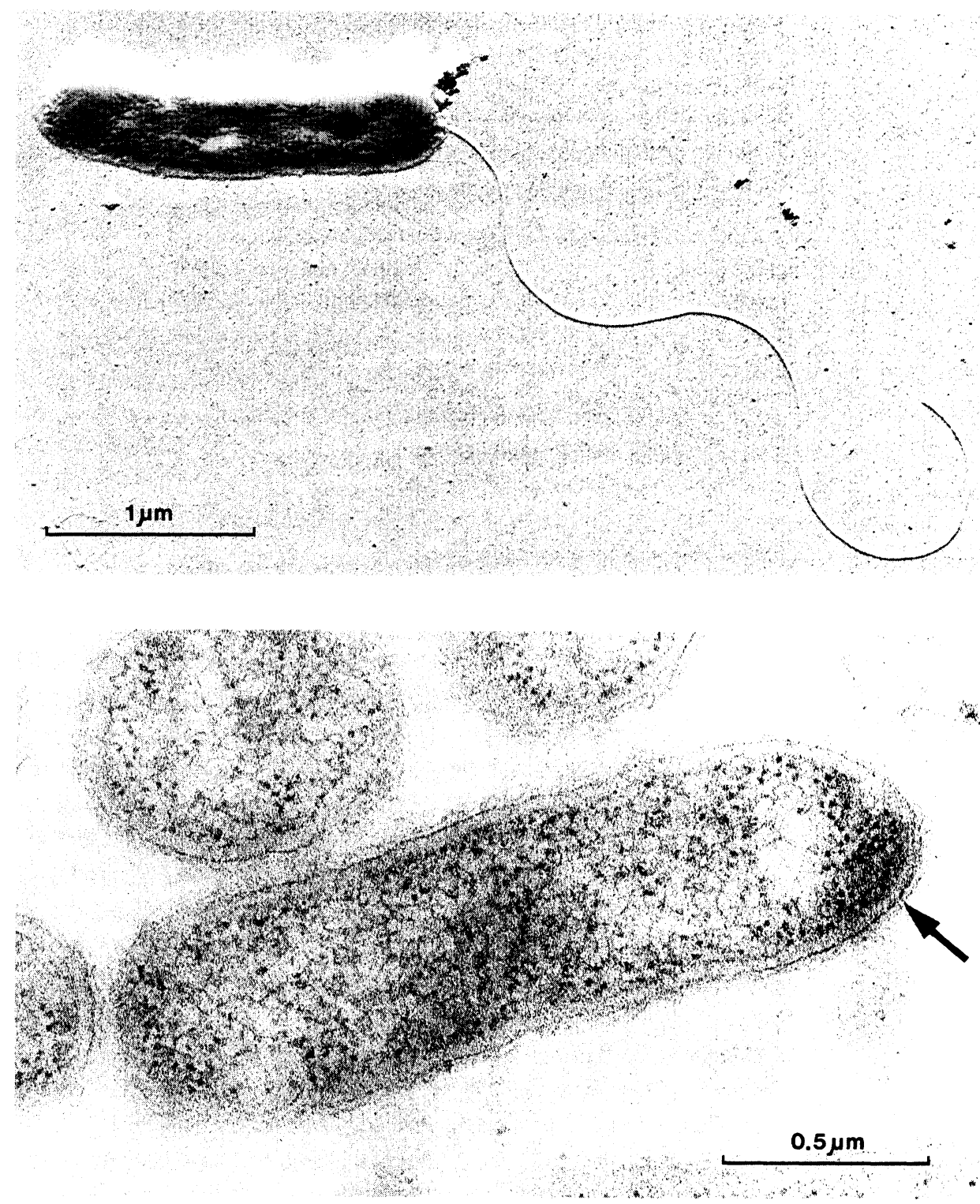

Fig. 1. Electron micrograph of Thiohacillus plumbophilus (isolate Gro7), shadowed unidirectionally with $\mathrm{Pt}$

\section{Growth temperature and $p H$ of growth}

The three isolates Gro3, Gro7 and Gro8 grew up to $41{ }^{\circ} \mathrm{C}$ with a temperature optimum between $21{ }^{\circ} \mathrm{C}$ and $34{ }^{\circ} \mathrm{C}$. The shortest doubling times were $24 \mathrm{~h}$ in the presence of $\mathrm{PbS}$ and $5 \mathrm{~h}$ in the presence of $\mathrm{H}_{2}$. At $9{ }^{\circ} \mathrm{C}$ doubling time of cells grown on $\mathrm{H}_{2}$ was $75 \mathrm{~h}$. Growth below $9{ }^{\circ} \mathrm{C}$ was not determined. The new isolates grew between $\mathrm{pH} 4.0$ and 6.5 . On $\mathrm{H}_{2} \mathrm{~S}$ growth was only determined qualitatively.

\section{Metabolism}

The new isolates grew aerobically on natural galena (e.g. Clausthal, FRG) and on synthetic PbS. The only metabolic product was anglesite $\left(\mathrm{PbSO}_{4}\right)$. Elemental sulfur was not detectable (D. Rose, personal communication). Due to the low solubility of lead sulfate, no rise of sulfate concentration in the liquid phase and, therefore, no drop of $\mathrm{pH}$ occurred during growth. Growth was neither stimulated nor inhibited by the addition of organic substrates. Elemental sulfur, thiosulfate, tetrathionate, the synthetic metal sulfides $\mathrm{Ag}_{2} \mathrm{~S}, \mathrm{CdS}, \mathrm{CuS}, \mathrm{CuS}_{2}, \mathrm{FeS}$, $\mathrm{HgS}, \mathrm{MoS}_{2}, \mathrm{Sb}_{2} \mathrm{~S}_{3}, \mathrm{SnS}$ and $\mathrm{ZnS}$, purified $\mathrm{UO}_{2}$ and the natural ores pyrite, chalcopyrite, sphalerite, and pitch blend did not serve as substrates. No oxidation of $\mathrm{Fe}^{2+}$ to $\mathrm{Fe}^{3+}$ was detectable neither when $\mathrm{FeSO}_{4}$ was the sole energy source nor in combination with $\mathrm{PbS}$.

$\mathrm{PbS}$ could be replaced by $\mathrm{H}_{2} \mathrm{~S}$, offered as a gradient within a soft agar column. The cells grew as a turbid ring, about $3 \mathrm{~mm}$ in height.

Alternatively the new isolates gain energy by aerobic hydrogen oxidation (Fig. 3). When $\mathrm{H}_{2}$ was replaced by $\mathrm{D}_{2}, \mathrm{HDO}$ was detectable by NMR spectroscopy (Fig. 4).

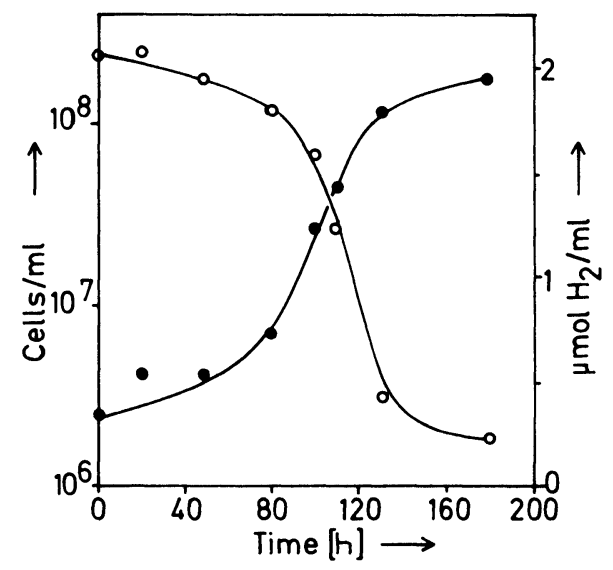

Fig. 3. Growth of Thiobacillus plumbophilus (isolate Gro7) by hydrogen oxidation. Symbols: $\bullet$. cell concentration; $\mathrm{O}, \mathrm{H}_{2}$ concentration 


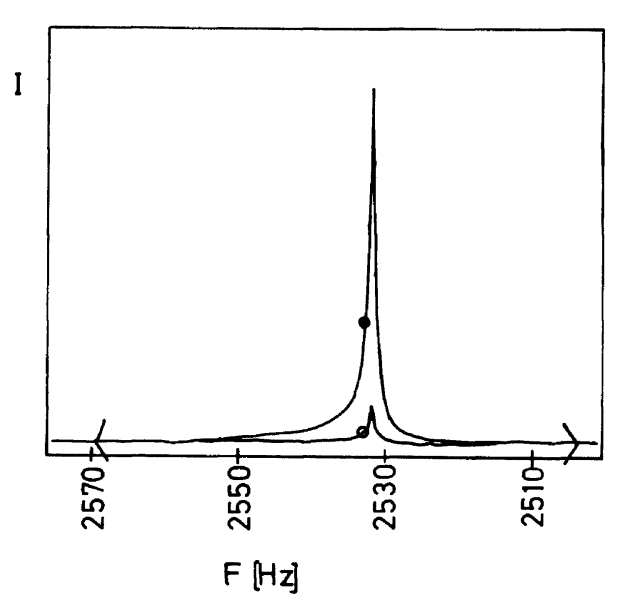

Fig. 4. NMR spectrograph of the liquid phases of cultures of Thiobacillus plumbophilus (isolate Gro7; $\bullet$; numerical value $=45.5$ ) and uninocculated medium $(O$; numerical value $=6.1)$; gas phase $\mathrm{D}_{2} / \mathrm{CO}_{2}$ /air. $\mathrm{I}=$ intensity; $\mathrm{F}=$ frequency; \langle\rangle$=$ integral

\section{Resistance to antibiotics}

Growth of the three isolates was totally inhibited by $50 \mu \mathrm{g} / \mathrm{ml}$ ampicillin and $100 \mu \mathrm{g} / \mathrm{ml}$ rifampicin.

\section{Resistance to heavy metals}

Isolate Gro7 grew in the presence of antimony, arsenic, cadmium, cobalt, copper, molybdenum, nickel, silver, uranium and zinc ions at $0.8,1.3,0.9,1.7,1.6,1,0.17$, 0.4 and $1.5 \mathrm{mmol} / 1$ respectively (Table 1 ). In comparison to Thiobacillus ferrooxidans, isolate Gro7 was more resistant against ions of cadmium and molybdenum, while it was more sensitive against ions of antimony, cobalt, copper, nickel and zinc. Furthermore, the isolates did not tolerate $\mathrm{Fe}^{2+}$ concentrations higher $2 \mathrm{mmol} / \mathrm{l}$.

\section{Content of quinones}

The new isolates contained ubiquinone $8\left(\mathrm{CoQ}_{8}\right)$ as their main quinone $(96.5 \%)$. Ubiquinone 10 was not detectable (D. Collins, personal communication).

Table 1. Heavy metal ion tolerances of isolate Gro7 (Thiobacillus plumbophilus) and T. ferrooxidans ( $\mathrm{mmol} / \mathrm{l})$

\begin{tabular}{llllll}
\hline Element & \multicolumn{2}{l}{ Isolate Gro7* } & & \multicolumn{2}{c}{ T. ferrooxidans* } \\
\cline { 2 - 3 } \cline { 5 - 6 } & growth & no growth & & growth & no growth \\
\hline $\mathrm{Ag}$ & 0.9 & n.d. & & 0.9 & n.d. \\
$\mathrm{As}$ & 1.3 & 13 & & 1.3 & 13 \\
$\mathrm{Cd}$ & 0.9 & 9 & & 0.09 & 0.9 \\
$\mathrm{Co}$ & 1.7 & 17 & & 17 & 85 \\
$\mathrm{Cu}$ & 1.6 & 16 & & 160 & 790 \\
$\mathrm{Fe}$ & 2.0 & 4 & & 250 & n.d. \\
$\mathrm{Mo}$ & 1 & 10 & & 0.1 & 1 \\
$\mathrm{Ni}$ & 0.17 & 1.7 & & 170 & 850 \\
$\mathrm{Sb}$ & 0.8 & 8 & & 8 & n.d. \\
$\mathrm{U}$ & 0.4 & 4 & & 0.4 & 4 \\
$\mathrm{Zn}$ & 1.5 & 15 & & 750 & 1530 \\
\hline
\end{tabular}

n.d. = not determined; precipitations

* grown on $\mathrm{PbS}$

** grown on ore mixture „G1“ (Huber and Stetter 1989)
Table 2. DNA-DNA homologies (\%) between the new isolates Gro7 and Gro8 and Thiobacillus reference strains T. ferrooxidans and $T$. cuprinus

\begin{tabular}{lcc}
\hline Filter-bound & \multicolumn{2}{c}{${ }^{32}$ P-labelled DNA from } \\
\cline { 2 - 3 } & Gro7 & Gro8 \\
\hline Gro7 & $(100)$ & 100 \\
Gro8 & 100 & $(100)$ \\
$T . f$. & 0 & 3 \\
T.c. & 7 & 0 \\
\hline T.f. $=$ Thiobacillus ferrooxidans & \\
T.c. $=$ Thiobacillus cuprinus &
\end{tabular}

\section{DNA base composition}

The $\mathrm{G}+\mathrm{C}$ content of the DNA was determined for the isolates Gro7 and Gro8. The organisms exhibited a $\mathrm{G}+\mathrm{C}$ content of around $66 \mathrm{~mol} \%$.

\section{DNA-DNA hybridization}

DNA-DNA hybridizations between isolates Gro7 and Gro8 exhibited a DNA homology of $100 \%$. No significant homology could be detected between the new isolates and Thiobacillus reference strains (Table 2).

\section{Discussion}

The new isolates are mesophilic, aerobic, Gram-negative tiny rods gaining energy by the oxidation of inorganic sulfur compounds. Therefore they are members of the genus Thiobacillus (Vishniac 1974). By 16S rRNA sequencing, isolate Gro7 belongs to the beta subdivision of the purple bacteria which contains also other members of Thiobacillus (Burggraf and Woese, personal communication; Huber and Stetter 1990). Since the new organisms are obligate chemolithotrophs and possess UQ-8, they are members of the group III of Thiobacillus (Katayama-Fujimura et al. 1982). The metal-mobilizers $T$. ferrooxidans and $T$. prosperus belong to the same group. Similar to $T$. ferrooxidans the new isolates are facultative hydrogen oxidizers (Drobner et al. 1990). However, they are different by (a) their slender tiny rod-shape of the cells, (b) an $8 \%$ higher $\mathrm{G}+\mathrm{C}$ content (66 mol \%) of their DNA, (c) their moderate acidophily, (d) their unability to oxidize ferrous iron, and (e) the lack of significant DNA-DNA homology. Therefore, the new isolates represent a new species within the genus Thiobacillus. Due to its utilization of galena as sole sulfidic ore we name it Thiobacillus plumbophilus, the leadloving Thiobacillus. Compared to $T$. ferrooxidans, the apparent lead specifity of $T$. plumbophilus could be explained by its much higher sensitivity against various heavy metal ions. Heavy metal ions become usually soluble during growth of ore-leaching bacteria on sulfidic ores. Anglesite $\left(\mathrm{PbSO}_{4}\right)$, however, the product of galena oxidation, is only very weakly soluble $\left(135 \mu \mathrm{mol} / 1\right.$ at $\left.20^{\circ} \mathrm{C}\right)$ and, therefore does not affect growth of $T$. plumbophilus. 
The natural biotope of T. plumbophilus is so far unknown. It could not be enriched from solfataric fields or sulfidic ore mines. Within the uranium mine close to Großschloppen, $T$. plumbophilus may grow on expense of lead compounds like galena which may have formed as decay products from uranium.

\section{Description of a new species}

Thiobacillus plumbophilus Drobner, Huber, Rachel, and Stetter, sp. nov. plum.bo'philus L. neut. n. plumbum, lead; Gr. verb. philein, to love; M. L. adj. plumbophilus loving lead, referring to its ability to grow with $\mathrm{PbS}$ as sole energy source.

Cells are rod-shaped, gram-negative, about $3 \mu \mathrm{m}$ long and $0.25 \mu \mathrm{m}$ in width, and are motile by one polar flagellum. Optimal growth between $21^{\circ} \mathrm{C}$ and $34^{\circ} \mathrm{C}$ and up to $41{ }^{\circ} \mathrm{C}$. Growth between pH 4.0 and 6.5. Strictly chemolithoautotrophic and aerobic. Oxidation of galena $(\mathrm{PbS}), \mathrm{H}_{2} \mathrm{~S}$ and $\mathrm{H}_{2}$. Sensitive to ampicillin and rifampicin, possess $96.5 \%$ ubiquinone $\mathrm{Q}-8 . \mathrm{G}+\mathrm{C}$ content of the DNA 66 mol \%. 16S rRNA sequence data show $T$. plumbophilus to be a member of the beta subdivision of the purple bacteria. Insignificant DNA hybridization to $T$. ferrooxidans and T. cuprinus. Isolated from an uranium mine in Germany.

Type strain is Thiobacillus plumbophilus, Gro7, DSM 6690, Braunschweig, FRG.

Acknowledgement. The excellent technical assistance of Lucia Schwarzfischer-Pfeilschifter is highly appreciated. We wish to thank Dr. E. Lang for NMR analyses, Dr. D. Collins for quinone analyses, Dr. D. Rose for cristallographic determination and Dr. K. E. Helmkampf of Saarberg Interplan for the opportunity to take samples. Thanks are also due to Dr. C. Woese and S. Burggraf for providing unpublished results of $16 \mathrm{~S}$ rRNA analyses, to Dr. A. Segerer for assaying hydrogenase activity and $\mathrm{H}$. Faust for electron microscopy.

This work was supported by grants of the Bundesministerium für Forschung und Technologie (BMFT, Projektleitung Rohstoffforschung, FKZ $03 \mathrm{C} 1420$ and $03 \mathrm{R} 085 \mathrm{~A}$ 2) and by the Fonds der Chemischen Industrie.

\section{References}

Baalsrud K, Baalsrud KS (1954) Studies on Thiobacillus denitrificans. Arch Mikrobiol 20: 34-62

Birnstiel ML, Sells BH, Purdom IF (1972) Kinetic complexity of RNA molecules. J Mol Biol 63: 21-39

Colmer AR, Hinkle ME (1947) The role of microorganisms in acid mine drainage: a preliminary report. Science 106: 253-256

Drobner E, Huber H, Stetter KO (1990) Thiobacillus ferrooxidans, a facultative hydrogen oxidizer. Appl Environ Microbiol 56: $2922-2923$
Gillespie S, Gillespie GD (1971) Ribonucleic acid - deoxyribonucleic acid hybridization in aqueous solutions and in solutions containing formamide. Biochem J 125: 481-487

Guay R, Silver M (1985) Thiobacillus acidophilus sp. nov., isolation and some physiological characteristics. Can J Microbiol 21: 281-288

Huber H, Huber G, Stetter KO (1985) A modified DAPI fluorescence staining procedure suitable for the visualization of lithotrophic bacteria. Syst Appl Microbiol 6: 105-106

Huber G, Huber H, Stetter KO (1986) Isolation and characterization of new metal-mobilizing bacteria. Biotechnol Bioeng Symp 16: 239-251

Huber H, Stetter KO (1989) Thiobacillus prosperus sp. nov., represents a new group of halotolerant metal-mobilizing bacteria isolated from a marine geothermal field. Arch Microbiol 151: 479-485

Huber H, Stetter KO (1990) Thiobacillus cuprinus sp. nov., a novel facultatively organotrophic metal-mobilizing bacterium. Appl Environ Microbiol 56: 315-322

Katayama- Fujimura Y, Tsuzaki N, Kuraishi H (1982) Ubiquinone, fatty acid and DNA base composition determination as a guide to the taxonomy of the genus Thiobacillus. J Gen Microbiol 128: $1599-1611$

Kelly DP (1988) Evolution of the understanding of the microbiology and biochemistry of the mineral leaching habitat. In: Norris PR, Kelly DP (eds) Biohydrometallurgy. Science and technology letters. Kew, Surrey, England, pp 3-14

Kelly RB, Cozzarelli NR, Deutscher MP, Lehmann JR, Kornberg A (1970) Enzymatic synthesis of deoxynucleic acid by polymerase at single strand break. J Biol Chem 245: 39-45

Kingma JG, Silver M (1980) Growth of iron-oxidizing Thiobacilli in the presence of chalcopyrite and galena. Appl Environ Microbiol 39: 635-641

König H (1984) Isolation and characterization of Methanobacterium uliginosum sp. nov. from a marshy soil. Can J Microbiol 30: $1477-1481$

Marmur J, Doty P (1962) Determination of the base composition of deoxyribonucleic acid from its thermal denaturation temperature. J Mol Biol 5: 109-118

Schink B, Schlegel HG (1979) The membrane-bound hydrogenase of Alcaligenes eutrophus. I. Solubilization, purification, and biochemical properties. Biochim Biophys Acta 567: 315-324

Torma AE, Sakaguchi H (1978) Relation between the solubility product and the rate of metal sulfide oxidation by Thiobacillus ferrooxidans. J Ferment Technol 56: 173-178

Silverman MP, Lundgren DG (1959) Studies on the chemoautotrophic iron bacterium Ferrobacillus ferrooxidans. I. An improved medium and a harvesting procedure for securing high cell yields. J Bacteriol 77: 642-647

Vishniac WV (1974) The genus Thiobacillus. In: Buchanan RE, Gibbons NE (eds) Bergey's manual of determinative bacteriology, 8th edn. Williams and Willkins, Baltimore, pp 456-461

Wildgruber G, Thomm M, König H, Ober K, Ricchiuto T, Stetter KO (1982) Methanoplanus limicola, a plate-shaped methanogen representing a novel family, the Methanoplanaceae. Arch Microbiol 132: $31-36$

Williams WJ (1979) Handbook of anion determination. Butterworths, London, pp 570-572

Zillig W, Stetter KO, Wunderl S, Schulz W, Priess H, Scholz I (1980) The Sulfolobus-"Caldariella" group: taxonomy on the basis of the structure of DNA-dependent RNA polymerases. Arch Microbiol 125: 259-269 